\title{
Safety, efficacy and quality profile of ayurvedic anti-cancer medicines
}

\author{
Chirra Jaji priya, Choppa Sai Sravani, Singh Kajal, Singh Vishal and Sinha Suhani * \\ G D Goenka University, Gurugram-122103, India.
}

Publication history: Received on 24 May 2020; revised on 03 July 2020; accepted on 06 July 2020

Article DOI: https://doi.org/10.30574/gscbps.2020.12.1.0152

\begin{abstract}
Cancer is a disease characterized by the uncontrolled multiplication of cells in human body with the inability to be controlled or stopped, consequently forming tumors of malignant cells with the potential to be metastatic. Around one third of deaths due to cancer are due to five leading behavioral and dietary risks: high body mass index, low fruit and vegetable intake, lack of physical activity, tobacco use and alcohol use. According to the World Health Organization, cancer is the second leading cause of death globally and about one in 6 deaths is due to cancer. The economic impact of cancer is significant and is increasing. The total annual economic cost of cancer in 2010 was estimated at approximately US 1.16 trillion. The economic burden on low- and middle-income countries is profound since approximately $70 \%$ of deaths due to cancer occur in these countries. To combat the growing challenge, development in cures and preventative therapies has emerged through rapid research in this area. Current treatments include chemotherapy, radiotherapy and chemically derived drugs which have severe side effects. Therefore, there is an increasing impetus on development and use of natural alternative therapies against cancer. Plants sources have been exploited in medicine for their natural antiseptic properties. Thus, research has developed into investigating the potential properties and uses of terrestrial plant extracts for the preparation of potential nanomaterial-based drugs for diseases including cancer. This article aims to take an overview of naturally derived compounds that have anticancer therapeutic properties and their current status in this field.
\end{abstract}

Keywords: Cow urine; Indian Gooseberry; Madagascar periwinkle; Garlic; Pacific Yew; Hemp plant

\section{Introduction}

Cancer has been a constant battle globally with a lot of development in cures and preventative therapies. The disease is characterized by cells in the human body continually multiplying with the inability to be controlled or stopped. Consequently, forming tumors of malignant cells with the potential to be metastatic. Current treatments include chemotherapy, radiotherapy and chemically derived drugs. Treatments such as chemotherapy can put patients under a lot of strain and further damage their health. Therefore, there is a focus on using alternative treatments and therapies against cancer. For many years herbal medicines have been used and are still used in developing countries as the primary source of medical treatment. Plants have been used in medicine for their natural antiseptic properties. Thus, research has developed into investigating the potential properties and uses of terrestrial plants extracts for the preparation of potential nanomaterial-based drugs for diseases including cancer. Many plant species are already being used to treat or prevent development of cancer. Multiple researchers have identified species of plants that have demonstrated anticancer properties with a lot of focus on those that have been used in herbal medicine in developing countries. Compounds which are characteristic to the plant kingdom and are necessary for plant survival and "housekeeping" of the organism are being investigated for their ability to inhibit growth and initiate apoptosis of cancerous cells.

\footnotetext{
${ }^{*}$ Corresponding author: Sinha Suhani
} 
Table 1 A Summary of ayurvedic anti-cancer products.

\begin{tabular}{|c|c|c|c|c|c|}
\hline S. No & $\begin{array}{l}\text { Common } \\
\text { Name }\end{array}$ & $\begin{array}{l}\text { Scientific } \\
\text { Name }\end{array}$ & Mechanism of action & Potential Indications & $\begin{array}{l}\text { Reference } \\
\mathbf{S}\end{array}$ \\
\hline 1. & Cow urine & $\begin{array}{l}\text { Gomutra } \\
\text { or } \\
\text { gaumutra }\end{array}$ & $\begin{array}{l}\text { Gomutra Ark is obtained from } \\
\text { distillation process of the cow urine. } \\
\text { There is very negligible content of } \\
\text { ammonia in Gomutra ark of cow } \\
\text { urine and it is palatable and } \\
\text { acceptable for patients. Study found } \\
\text { that cow urine distillate; Gomutra } \\
\text { Arka has antioxidant potential and } \\
\text { immuno modulatory effect. }\end{array}$ & $\begin{array}{l}\text { Evaluation of cow urine } \\
\text { therapy on } 8 \text { cancer } \\
\text { patients at Mandsaur } \\
\text { district was carried out. } \\
\text { During survey, out of } 68 \\
\text { patients, } 7.35 \% \text { patients } \\
\text { withdrew themselves } \\
\text { from the treatment and } \\
63 \text { (92.64\%) patients } \\
\text { continued the therapy. } \\
\text { There was a high } \\
\text { proportion (30.87\%) of } \\
\text { throat cancer and the } \\
\text { other prevalent cancer } \\
\text { was breast cancer } \\
(14.70 \%) \text { followed by } \\
\text { cervix and uterine } \\
\text { cancer (5.88\%), buccal } \\
\text { cavity cancer and sinus } \\
(4.41 \%) \text { lung cancer, } \\
\text { lymphoma and bone } \\
\text { cancer (2.94\%), both } \\
\text { throat and buccal } \\
(5.88 \%) \text { and other } \\
\text { cancer } \\
(8.82 \%), \text { respectively. }\end{array}$ & [1] \\
\hline 2. & $\begin{array}{l}\text { Indian } \\
\text { Gooseberry }\end{array}$ & $\begin{array}{l}\text { Phyllanthus } \\
\text { emblica }\end{array}$ & $\begin{array}{l}\text { P. emblica exhibits its anticancer } \\
\text { activities through inhibition of } \\
\text { activator protein AP-1 and targets } \\
\text { transcription of viral oncogenes } \\
\text { responsible for development and } \\
\text { progression of cervical cancer thus } \\
\text { indicating its possible utility for } \\
\text { treatment of HPV-induced cervical } \\
\text { cancers. }\end{array}$ & Cervical cancer & [2] \\
\hline 3. & $\begin{array}{l}\text { Madagascar } \\
\text { Periwinkle }\end{array}$ & $\begin{array}{l}\text { Catharanth } \\
\text { us roseus }\end{array}$ & $\begin{array}{l}\text { Mechanism of action of the drug in } \\
\text { tumorous cells involves } \\
\text { stabilization of cellular } \\
\text { microtubules through binding } \beta \text { - } \\
\text { tubulin subunit, leading to } \\
\text { interference with their normal } \\
\text { breakdown during cell division } \\
\text { with resultant stabilization of the } \\
\text { polymer through protection from } \\
\text { disassembly }\end{array}$ & $\begin{array}{l}\text { Breast cancer, } \\
\text { Ovarian cancer and } \\
\text { Lung cancer. }\end{array}$ & [3] \\
\hline 4 & Garlic & $\begin{array}{l}\text { Allium } \\
\text { sativum }\end{array}$ & $\begin{array}{l}\text { The most-effective way of treating } \\
\text { cancer by raw garlic extract may be } \\
\text { the direct injection instead of eating } \\
\text { the cooked garlic. Garlic contains } \\
\text { allicin }\end{array}$ & $\begin{array}{l}\text { Reduces inflammations } \\
\text { in stomach, prostate and } \\
\text { colorectal cancers }\end{array}$ & [4] \\
\hline
\end{tabular}




\begin{tabular}{|c|c|c|c|c|c|}
\hline 5 & Pacific Yew & $\begin{array}{l}\text { Taxus } \\
\text { brevifolia }\end{array}$ & $\begin{array}{l}\text { These chemicals help to stop } \\
\text { new cancer cells forming, Known as } \\
\text { Taxane, they do this by disrupting } \\
\text { the function of microtubules in our } \\
\text { bodies, key players in the process of } \\
\text { cell division. Taxotere has proven } \\
\text { effective in combating lung and } \\
\text { prostate cancer and advanced cases } \\
\text { of breast cancer. }\end{array}$ & $\begin{array}{l}\text { Ovarian cancer. } \\
\text { Lung cancer, } \\
\text { prostate cancer and } \\
\text { advanced cases of } \\
\text { breast cancer. }\end{array}$ & [5] \\
\hline 6 & $\begin{array}{l}\text { Mayapple } \\
\text { treatment }\end{array}$ & $\begin{array}{l}\text { American } \\
\text { Mandrake }\end{array}$ & $\begin{array}{l}\text { Podophyllotoxin is the starting } \\
\text { material for the semi-synthesis of } \\
\text { the anti-cancer drugs etoposide, } \\
\text { teniposide and etopophos. These } \\
\text { compounds have been used for the } \\
\text { treatment of lung and testicular } \\
\text { cancers as well as certain } \\
\text { leukemias. It is also the precursor to } \\
\text { a new derivative CPH } 82 \text { that is } \\
\text { being tested for rheumatoid } \\
\text { arthritis in Europe, and it is the } \\
\text { precursor to other derivatives used } \\
\text { for the treatment of psoriasis and } \\
\text { malaria. Several Podophyllotoxin } \\
\text { preparations are on the market for } \\
\text { dermatological use to treat genital } \\
\text { warts. Since the total synthesis of } \\
\text { Podophyllotoxin is an expensive } \\
\text { process, availability of the } \\
\text { compound from natural renewable } \\
\text { resources is an important issue for } \\
\text { pharmaceutical companies that } \\
\text { manufacture these drugs. }\end{array}$ & $\begin{array}{l}\text { The risk of toxicity is too } \\
\text { high to recommend } \\
\text { home use. Classical use } \\
\text { of Mayapple resin as a } \\
\text { purgative used } 10 \mathrm{mg} \\
\text { doses. A } 20 \% \text { suspension } \\
\text { in petrolatum has been } \\
\text { used. Pure } \\
\text { Podophyllotoxin was } \\
\text { formulated at } 0.5 \% \text { to } \\
2 \% \text { in a recent clinical } \\
\text { trial for treatment of } \\
\text { penile warts. }\end{array}$ & [6] \\
\hline 7 & Hemp plant & $\begin{array}{l}\text { Cannabis } \\
\text { Sativa L }\end{array}$ & $\begin{array}{l}\text { Cannabidiol, or CBD, is one of many } \\
\text { cannabinoids in the cannabis plant } \\
\text { gaining popularity in the world of } \\
\text { natural medicine because it appears } \\
\text { to offer the body many benefits. } \\
\text { While there is some debate around } \\
\text { the topic, some people suggest } \\
\text { using CBD in the treatment of } \\
\text { cancer. }\end{array}$ & $\begin{array}{l}\text { Remember, that dosing } \\
\text { CBD oil depends on the } \\
\text { product. Most } \\
\text { companies provide CBD } \\
\text { dosing guidelines on the } \\
\text { bottle, but those } \\
\text { guidelines are specific to } \\
\text { the potency of the } \\
\text { product. What this } \\
\text { means is, the dosing } \\
\text { chart on a } 1000 \text { mg CBD } \\
\text { drops would not be ideal } \\
\text { for someone who is } \\
\text { highly sensitive to CBD } \\
\text { and could do better with } \\
\text { the potency of 250mg } \\
\text { CBD drops. } \\
\text { When consuming CBD, it } \\
\text { could be useful to use a } \\
\text { notebook or an app to } \\
\text { chart any changes you } \\
\text { find in your mood, sleep, } \\
\text { and general wellbeing. } \\
\text { You could use this as a } \\
\text { guide to determine the } \\
\text { best CBD dose and best }\end{array}$ & [7] \\
\hline
\end{tabular}




\begin{tabular}{|c|c|c|c|c|c|}
\hline & & & & $\begin{array}{l}\text { CBD dosage schedule for } \\
\text { yourself. }\end{array}$ & \\
\hline 8 & Cow milk & 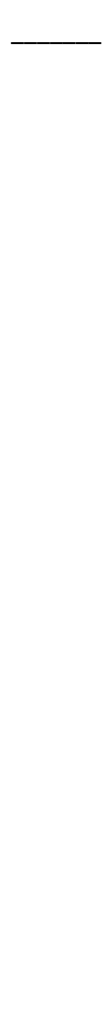 & $\begin{array}{l}\text { Milk is considered to be the only } \\
\text { foodstuff that contains } \\
\text { approximately all different } \\
\text { substances known to be essential } \\
\text { for human nutrition. In terms of } \\
\text { cancer risk, dairy foods have been } \\
\text { reported as both protective and } \\
\text { occasionally as harmful. The } \\
\text { evidence that dairy foods can } \\
\text { protect against cancer, or increase } \\
\text { the risk of cancer is not conclusive. } \\
\text { Overall, the proven health benefits } \\
\text { of dairy foods greatly outweigh the } \\
\text { unproven harm. Dairy foods should } \\
\text { be encouraged as part of a varied } \\
\text { and nutritious diet as they are } \\
\text { essential to maintain good bone and } \\
\text { dental health, to prevent } \\
\text { osteoporosis, major cardiovascular } \\
\text { disease risk factors, hypertension, } \\
\text { type-2 diabetes, metabolic } \\
\text { syndromes, as well as some cancers. } \\
\text { The Cancer Council and USFDA } \\
\text { recommend } 3 \text { servings of milk and } \\
\text { milk products daily. }\end{array}$ & 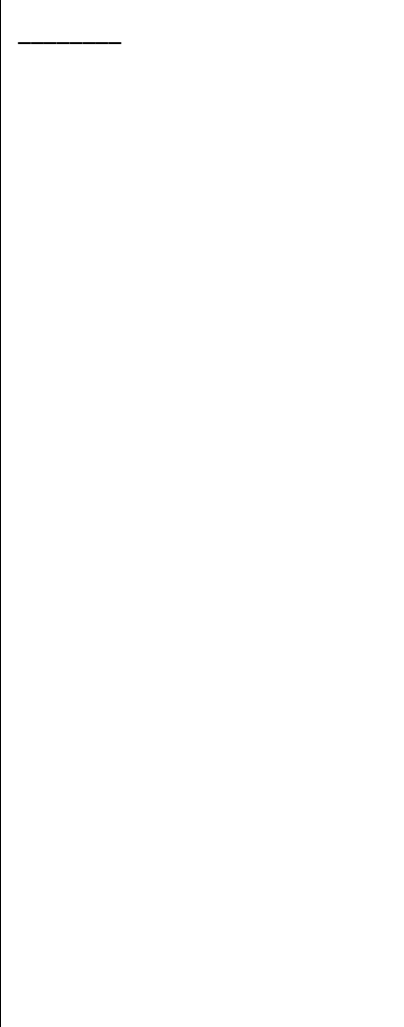 & [8] \\
\hline 9 & $\begin{array}{l}\text { Red sand } \\
\text { boa snake }\end{array}$ & & $\begin{array}{l}\text { Many active secretions produced by } \\
\text { animals have been employed in the } \\
\text { development of new drugs to treat } \\
\text { diseases such as hypertension and } \\
\text { cancer. Snake venom toxins } \\
\text { contributed significantly to the } \\
\text { treatment of many medical } \\
\text { conditions. There are many } \\
\text { published studies describing and } \\
\text { elucidating the anti-cancer } \\
\text { potential of snake venom. Cancer } \\
\text { therapy is one of the main areas for } \\
\text { the use of protein peptides and } \\
\text { enzymes originating from animals } \\
\text { of different species. Some of these } \\
\text { proteins or peptides and enzymes } \\
\text { from snake venom when isolated } \\
\text { and evaluated may bind specifically } \\
\text { to cancer cell membranes, affecting } \\
\text { the migration and proliferation of } \\
\text { these cells. Some of substances } \\
\text { found in the snake venom present a } \\
\text { great potential as anti-tumor agent. }\end{array}$ & $\begin{array}{l}\text { Initial interaction of } \\
\text { venom peptides with the } \\
\text { target molecule is the } \\
\text { first and foremost step } \\
\text { which plays a key role in } \\
\text { venom-peptide induce } \\
\text { anti-cancer activity. } \\
\text { Many of the examples } \\
\text { used in this review } \\
\text { emphasize the } \\
\text { importance of this initial } \\
\text { step. This interaction is } \\
\text { guided either by the } \\
\text { polarity of a molecule or } \\
\text { by specific } \\
\text { pharmacophore domain. } \\
\text { Followed by initial } \\
\text { interactions, peptides } \\
\text { tend to exhibit their } \\
\text { effects mostly by } \\
\text { membrane interactions, } \\
\text { although many other } \\
\text { mechanisms such as } \\
\text { intracellular peptide- } \\
\text { protein interaction, } \\
\text { peptide-DNA tha } \\
\text { interactions still exist. } \\
\text { The targeted therapy }\end{array}$ & [9] \\
\hline
\end{tabular}




\begin{tabular}{|c|c|c|c|c|c|}
\hline & & & & $\begin{array}{l}\text { drug with the specificity } \\
\text { on certain molecule } \\
\text { determines the } \\
\text { limitation of its use, for } \\
\text { example trastuzumab } \\
\text { can only be used for } \\
\text { HER2-positive breast } \\
\text { cancer which occupy } \\
\text { about } 20 \% \text { of breast } \\
\text { cancer patients. Drugs } \\
\text { derived from venom are } \\
\text { no exception. Currently, } \\
\text { venom-based drugs such } \\
\text { as chlorotoxin and } \\
\text { integrin } \alpha v \beta 3 \text { drugs are } \\
\text { used mainly in brain } \\
\text { tumor and cancer with } \\
\text { overexpressed } \alpha v \beta 3 \text {, } \\
\text { respectively. }\end{array}$ & \\
\hline 10 & Turmeric & $\begin{array}{l}\text { Curcuma } \\
\text { longa }\end{array}$ & $\begin{array}{l}\text { The molecular mechanism and } \\
\text { targets through which curcumin } \\
\text { modulates cell cycle, apoptotic } \\
\text { signals, anti-apoptotic proteins, } \\
\text { miRNAs, Wnt/beta-catenin } \\
\text { signaling, protein kinases, nuclear } \\
\text { factor-kB, proteasome activation, } \\
\text { epigenetic regulation including } \\
\text { DNA methylation and histone } \\
\text { modification. Curcumin reverses } \\
\text { the multi-drug resistance (MDR) of } \\
\text { cancer cells. }\end{array}$ & $\begin{array}{l}\text { Clinical trials are } \\
\text { research studies that } \\
\text { involve people. The } \\
\text { clinical trials on this list } \\
\text { are studying Curcumin. } \\
\text { NCI's explains the types } \\
\text { and phases of trials and } \\
\text { how they are carried out. } \\
\text { Clinical trials look at new } \\
\text { ways to prevent, detect, } \\
\text { or treat disease. }\end{array}$ & [10] \\
\hline 11 & Neem plant & $\begin{array}{l}\text { Azadiractha } \\
\text { indica }\end{array}$ & $\begin{array}{l}\text { Neem compounds present in bark, } \\
\text { leaves, flowers, and seed oil have } \\
\text { been shown to possess chemo } \\
\text { preventive properties, apoptotic } \\
\text { activities, immunomodulatory } \\
\text { effects, and induction of p53- } \\
\text { independent apoptosis. }\end{array}$ & $\begin{array}{l}\text { cervical cancer, ovarian } \\
\text { cancer, breast cancer }\end{array}$ & [11] \\
\hline 12 & Broccoli & $\begin{array}{l}\text { Brassica } \\
\text { oleracea } \\
\text { var. italica. }\end{array}$ & $\begin{array}{l}\text { Sulforaphane (SFN) is a metabolic } \\
\text { by product of cruciferous } \\
\text { vegetables found in high } \\
\text { concentrations in broccoli. It has } \\
\text { been studied extensively for its } \\
\text { anticancer efficacy and the } \\
\text { underlying mechanisms using cell } \\
\text { culture and preclinical models. SFN } \\
\text { and other notable isothiocyanates, } \\
\text { including phenethyl isothiocyanate } \\
\text { and benzyl isothiocyanate found in } \\
\text { various cruciferous vegetables, } \\
\text { have also been implicated to have a } \\
\text { chemo preventive role for breast, } \\
\text { colon and prostate cancer. }\end{array}$ & $\begin{array}{l}\text { Prostate cancer. } \\
\text { Breast cancer } \\
\text { Colon cancer. }\end{array}$ & [12] \\
\hline
\end{tabular}




\section{Conclusion}

Any practical solution to controlling the progression of cancer is of paramount importance. The use of medicinal plant products to manage or arrest the carcinogenic process provides an alternative to the use of conventional allopathic medicine for treatment of the disease. Many herbs have been evaluated in clinical studies and are currently being investigated to understand their tumoricidal properties against various cancers. Now it is important to raise awareness and encourage implementation of Ayurvedic therapies for combating cancer and suggest an integrated approach in tumor management and treatment.

\section{Compliance with ethical standards}

\section{Acknowledgments}

We are using this opportunity to express our gratitude to everyone who supported us. We are thankful for their constant guidance, invaluable and constructive criticism advice during the project work. We are sincerely grateful to them for sharing their helpful and educational views on a number of issues related to the project.

\section{Disclosure of conflict of interest}

All author(s) declare(s) that there is no conflict of interest. If there are potential conflicts of interest, we highly encourage each author to identify and declare clearly to avoid any future investigations by the publisher.

\section{References}

[1] Jain NK, Gupta VB, Garg R and Silawat N. (2010). Efficacy of cow urine therapy on various cancer patients in Mandsaur District, India - A survey. International Journal of Green Pharmacy, 4(1).

[2] Zhao T, Sun Q,Marques M and Witcher M.(2015). Anticancer Properties of Phyllanthus emblica (Indian Gooseberry). Oxid Med Cell Longev.

[3] Moudi M, Go R, Yien CYS and Nazre M. (2013). Vinca Alkaloids. International Journal of Preventive Medicine, vol. $4(11), 1231-1235$.

[4] Li Z, Le W and Cui Z. (2018). A novel therapeutic anticancer property of raw garlic extract via injection but not ingestion. Cell Death Discovery, 108.

[5] BA, Weaver. (2014). How Taxol/paclitaxel kills cancer cells. Molecular Biology of the Cell, vol. 25(18), $2677-2681$.

[6] Chang LW, Yang CM, Chen CF and Deng JF. (1992). Experimental podophyllotoxin (bajiaolian) poisoning: I. Effects on the nervous system. Biomed Environ Sci, 5, 283-292.

[7] Pawel S, Joanna Z, Ryszard S and Agnieszka N. (2018). The current state and future perspectives of cannabinoids in cancer biology. Cancer Med, 7(3), 765-775, Cancer Med, vol. 7(3), 765-775.

[8] Gill HS and Cross ML. (2000). Anticancer Properties of Bovine Milk. Br J Nutr, vol. 84(1)161-6.

[9] Sanchez EF, Schneider FS, Yarleque A, Borges MH, Richardson M, Figueredo SG, et al. (2010). The novel metalloproteinase Atrox lysin-I from Peruvian Bothrops atrox (Jergon) snake venom acts both on blood vessel ECM and platelets. Arch Biochem Biophy, 496.

[10] G, Giordano A and Tommonaro. (2019). Curcumin and Cancer. Nutrients, vol. 11(10).

[11] Moga MA, Bălan A, Anastasiu CV, Dimienescu OG, Neculoiu CD, and Gavriș C. (2018). An Overview on the Anticancer Activity of Azadirachta indica (Neem) in Gynecological Cancers. International Journal of Molecular Sciences, 19(12).

[12] Amjad AI, Parikh RA, Appleman LJ, Hahm ER, Singh K, and Singh SV. (2015) Broccoli-Derived Sulforaphane and Chemoprevention of Prostate Cancer: From Bench to Bedside. Curr Pharmacol Rep, 1(6), 382-390.

\section{How to cite this article}

Chirra JP, Choppa SS, Singh K, Singh V and Sinha S. (2020). Safety, efficacy and quality profile of ayurvedic anti-cancer medicines. GSC Biological and Pharmaceutical Sciences, 12(1), 01-06. 